\title{
Valence isomerization of cyclohepta-1,3,5-triene and its heteroelement analogues
}

\author{
Helen Jansen, J. Chris Slootweg and Koop Lammertsma*
}

\section{Review}

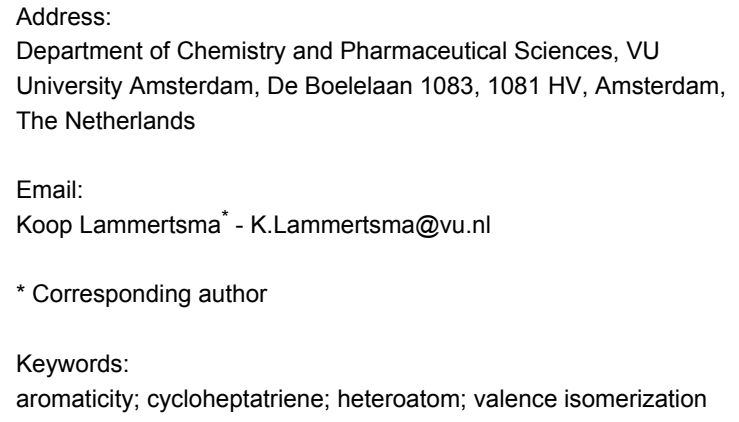

\begin{abstract}
The valence isomerization of the all-carbon and heteroelement analogues of cyclohepta-1,3,5-triene into the corresponding bicyclo[4.1.0]hepta-2,4-dienes is reviewed to show the impact of the heteroatom on the stability of both valence isomers. The focus is on the parent systems and their synthetic applications.
\end{abstract}

\section{Introduction}

The valence isomerization of cyclohepta-1,3,5-triene (1) into bicyclo[4.1.0]hepta-2,4-diene (2) has captured the attention of chemists for over five decades $[1,2]$. This interest extended to the heterocyclic analogues 3-8, bearing one oxygen, sulfur or nitrogen atom, after the discovery of their biological importance (Scheme 1) [3,4]. The phosphane analogues 9 and 10 received far less attention, with their applicability as a phosphinidene (R-P) precursor being the most notable use [5-9].

Reviewing the influence of the heteroatom on the cycloheptatriene-norcaradiene valence isomerization necessitates a brief overview of the parent all-carbon system. This section is followed by one in which experimental data on the oxepine, thiepine, $1 H$-azepine, and $1 H$-phosphepine valence isomerizations are compared with those obtained by theoretical calculations. Computational methods have the advantage that they enable reliable insight into the reaction energies and aromatic features of the parent isomers. In this brief review, only selected examples of substituted heteropines and their syntheses are given.

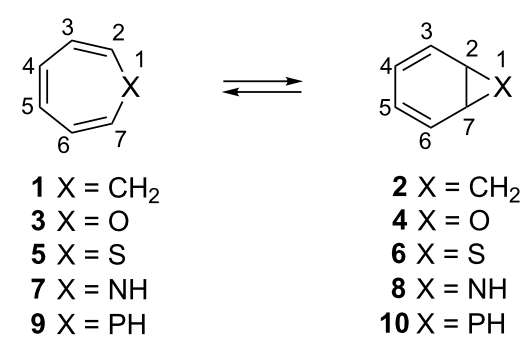

Scheme 1: Valence isomerization of cyclohepta-1,3,5-triene (1) and its heteroelement analogues. 


\section{Review}

\section{Cycloheptatriene valence isomerization}

Cyclohepta-1,3,5-triene (1), first isolated in 1883 [10], has a boat-shaped conformation as determined by electron diffraction [11] and microwave studies of the parent [12] and by an X-ray structure analysis of the derivative thujic acid $[13,14]$. These methods gave inconsistent $\alpha$ and $\beta$ tilt angles (see Scheme 2 for a description of the bow $(\alpha)$ and stern ( $\beta$ ) tilt angles) with those determined by electron diffraction standing out. Theoretical calculations at the B3LYP/6-311+G(d,p) level gave $\alpha$ and $\beta$ angles of $52.9^{\circ}$ and $25.4^{\circ}$, respectively [15-17], which are in reasonable harmony with those of the microwave and X-ray studies. Low temperature ${ }^{1} \mathrm{H}$ NMR measurements showed that the slightly homoaromatic boat conformation is prone to undergo a degenerate ring flip via an antiaromatic $C_{2 v}$ transition with a free energy barrier of $5.7 \mathrm{kcal} \cdot \mathrm{mol}^{-1}$ in $\mathrm{CBrF}_{3}$ [18] and $6.3 \mathrm{kcal} \cdot \mathrm{mol}^{-1}$ in $\mathrm{CF}_{2} \mathrm{Cl}_{2}[19-21]$.

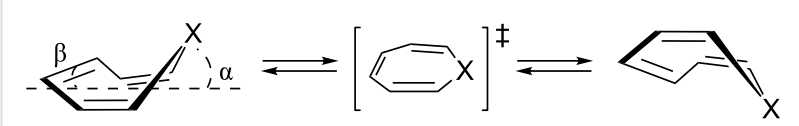

Scheme 2: Conformational ring inversions.

Cycloheptatriene is in equilibrium with bicyclo[4.1.0]hepta-2,4diene (2) by means of a Woodward-Hoffmann symmetryallowed disrotatory ring closure [22,23]. Although the equilibrium strongly favours the seven-membered ring, the presence of small quantities of the bicyclic isomer 2 was inferred by Diels-Alder trapping reactions [24]. In 1981, Ruben was the first to observe norcaradiene (2) directly, by employing lowtemperature photolysis, and an activation barrier of $11 \pm 2$ $\mathrm{kcal} \cdot \mathrm{mol}^{-1}$ was determined for the formation of $\mathbf{2}$ from $\mathbf{1}$, with the product being $4 \mathrm{kcal} \cdot \mathrm{mol}^{-1}$ less stable [25]. Strong electronwithdrawing groups at the methylene bridge influence the 1-2 equilibrium in favour of the norcaradiene isomer, as is the case for the thermally stable 7,7-dicyano-derivative [26,27]. At the
B3LYP/6-311+G(d,p) level the geometry of the parent was shown to have a straighter bow $\left(\alpha=65.8^{\circ}\right)$ and flatter stern $\left(\beta=18.9^{\circ}\right)$ as compared to cyclohepta-1,3,5-triene [14].

Besides the 1-2 interconversion, the $\mathrm{C}_{7} \mathrm{H}_{8}$ system is rich in rearrangements (Scheme 3). In 1957, Woods found that bicyclo[2.2.1]hepta-2,5-diene (12) converts to cycloheptatriene (1), which was postulated to proceed via diradical $\mathbf{1 1}$ and norcaradiene (2) [28]. Instead, pyrolysis of 1 yielded toluene, presumably through a [1,3]-H shift of the diradical [29]. Norcaradiene (2) can also undergo a [1,5]-carbon circumambulatory rearrangement ("walk"), as was discovered by Berson and Willcott in 1965 [30,31]. Although, this process should proceed with retention of the configuration according to the symmetry conservation rules, studies of chiral substituted cycloheptatrienes showed a preference for the "forbidden" path with inversion of configuration [32-35]. Finally, a suprafacial [1,5]hydrogen shift with an activation energy of approximately $31 \mathrm{kcal} \cdot \mathrm{mol}^{-1}$ was unveiled by a high-temperature NMR study $\left(100-140{ }^{\circ} \mathrm{C}\right)$ of hydrogen isotopomers of cycloheptatriene (Scheme 3) [36-38].

\section{Valence isomerization of heteropines}

Determining the conformations of the heteropines has been more of a challenge. Only the parent oxepine (3) is isolable at room temperature. NMR spectroscopy indicated a boat-shape structure with alternating $\mathrm{C}=\mathrm{C}$ bonds for 3 [39,40], which was supported by single-crystal X-ray structure analyses of simple derivatives [41]. Table 1 also summarizes the relative energies obtained by high-level theoretical calculations for the parent heteropines and the corresponding bicyclic norcaradienes, and the barriers for their interconversion and ring inversion.

Although the boat form prevails for the monocyclic heteropines $\mathbf{1}, \mathbf{3}$ and 5, Cremer et al. showed that this represents an incomplete picture $[43,44]$. In fact, they are "perturbed" boats with at least $22 \%$ chair character, leading to an almost similar boat

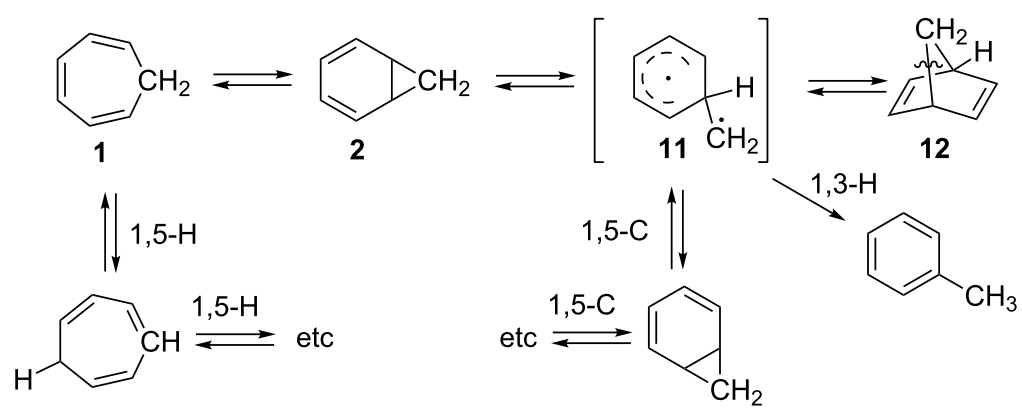


Table 1: Relative energies (in kcal $\cdot \mathrm{mol}^{-1}$ ) of the norcaradienes (NCD) $2(\mathrm{C}), \mathbf{4}(\mathrm{O}), \mathbf{6}(\mathrm{S}), \mathbf{8}(\mathrm{N}), \mathbf{0}(\mathrm{P})$, the cycloheptatrienes $(\mathrm{CHT}) \mathbf{1}(\mathrm{C}), \mathbf{3}(\mathrm{O}), \mathbf{5}(\mathrm{S})$, $7(\mathrm{~N}), 9(\mathrm{P})$, their interconversion barriers, and the barriers for ring inversion of the monocycles.

\begin{tabular}{|c|c|c|c|c|c|c|}
\hline & NCD & TS & $\mathrm{CHT}$ & $\mathrm{TS}_{\text {inv }}$ & Method $^{a}$ & Ref \\
\hline$C(1,2)$ & 4 & $11^{b}$ & 0.0 & $\sim 6$ & Exp. & {$[17,18,24]$} \\
\hline \multirow[t]{2}{*}{$O(3,4)$} & 0.0 & $9.1^{\mathrm{C}}$ & 1.7 & - & NMR & {$[38,39]$} \\
\hline & 0.0 & 7.0 & 0.1 & 3.5 & QCISD $(T) / 6-31 G(d)$ & {$[40]$} \\
\hline$S(5,6)$ & 0.0 & $20.5^{c}$ & 7.0 & 7.3 & QCISD(T)/6-31G(d) & {$[40]$} \\
\hline$N(7,8)$ & 7.9 & $11.4^{b}$ & 0.0 & $\sim 3$ & B3LYP/6-31G(d) & {$[41,42,44]$} \\
\hline$P(9,10)$ & 0.0 & 15.7 & 2.5 & 5.2 & B3LYP/6-311+G(d,p) & {$[7,45]$} \\
\hline
\end{tabular}

${ }^{a}$ Gibbs free energies for the experimental data (first two entries) and enthalpies for the computational data. ${ }^{b}$ Equilibrium from $\mathrm{CHT}$ to NCD. 'Equilibrium from NCD to $\mathrm{CHT}$.

puckering for all. From the racemization of substituted benzene oxides (Scheme 2), the oxepine ring inversion barrier was estimated at $6.5 \mathrm{kcal} \cdot \mathrm{mol}^{-1}$ at $135 \mathrm{~K}[45,46]$, which is similar to the $3.5 \mathrm{kcal} \cdot \mathrm{mol}^{-1}$ calculated for the parent oxepine (3) at the QCISD(T)/6-31G(d) level [40]. The calculated barrier of $8.3 \mathrm{kcal} \cdot \mathrm{mol}^{-1}$ for thiepine (5) is nearly twice as large, possibly due to the higher antiaromatic destabilization of the flattened thiepine ring [40], but the interconversion of the boat forms of azepine and phosphepine are about equally favourable, requiring 3.0 [41] and $5.2 \mathrm{kcal} \cdot \mathrm{mol}^{-1}[7,47]$, respectively.

A question related to the valence isomerization is whether aromatic properties can be ascribed to the heteropines. Indeed, the monocyclic boat-shaped heteropines exhibit homoaromatic features by conjugative interaction of the triene unit through 1,6-overlap of $2 p \pi$-orbitals [41], as is the case for cyclohepta1,3,5-triene (1) $[19,20]$. Through the use of nucleus-independent chemical shifts (NICS(1)) [48], it was shown that thiepine (-2.3 ppm) [49] and phenyl phosphepine (-4.8 ppm) [7] display aromatic character when compared to the wellknown $6 \pi$-electron Hückel-aromatic tropylium cation [46], which has a NICS(1) value of $-8.2 \mathrm{ppm}$. Adding electronegative substituents enhances the effect, and fully aromatic systems are obtained after complete fluorination of the heteropines (Figure 1) [50]. In contrast, the flattened transition structures for ring inversion of thiepine and phosphepine are indeed highly antiaromatic planar $8 \pi$-electron systems, with positive $\operatorname{NICS}(1)$ values of 19.3 [47] and $6.4 \mathrm{ppm}$ [7], respectively. The inherent instability of thiepine (5) has been attributed to this effect $[51,52]$.

\section{Oxepine - benzene oxide}

Oxepine (3) was isolated first by Vogel et al. using a double dehydrohalogenation of 1,2-dibromo-4,5-epoxycyclohexane $[38,53]$, but is also accessible by epoxidation of Dewar benzene followed by photolytic or thermal ring expansion [54]. The molecular structure of the 2-tert-butoxycarbonyl oxepine showed a boat configuration with bow $(\alpha)$ and stern $(\beta)$ fold angles of $56.5^{\circ}$ and $26.0^{\circ}$, respectively [44], which differs little from the MP2/6-31G(d) geometry of the parent 3 ( $C_{s}$ symmetry; $\alpha=58.3^{\circ}, \beta=30.8^{\circ}$ ), illustrating that the substituent hardly influences the geometry [40]. Oxepine (3) is more curved than cyclohepta-1,3,5-triene $\left(1 ; \alpha=52.9^{\circ}, \beta=25.4^{\circ}\right.$; same level of theory) [14].

Using ${ }^{1} \mathrm{H}$ NMR spectroscopy, Vogel and Günther determined that 7-oxa-bicyclo[4.1.0]hepta-2,4-diene (4, benzene oxide; Scheme 4) is $1.7 \mathrm{kcal} \cdot \mathrm{mol}^{-1}$ more stable than monocyclic 3 in apolar solvents [38,39], with an activation barrier for the conversion of 3 to 4 of $7.2 \mathrm{kcal} \cdot \mathrm{mol}^{-1}$. Calculations at the QCISD(T)/6-31G(d) level confirm the bicyclic form to be the most stable isomer, albeit with an energy difference of a mere $0.1 \mathrm{kcal} \cdot \mathrm{mol}^{-1}$ and a barrier to interconversion of $9.1 \mathrm{kcal} \cdot \mathrm{mol}^{-1}$ [40]. By changing to more polar solvents, the oxepine isomer-

\footnotetext{
Figure 1: $\mathrm{NICS}(0)$ values of fluorinated heteropines.
} 
ization equilibrium shifts further toward benzene oxide (more positive $\Delta G$ ), suggesting that benzene oxide has the larger dipole moment. Methyl substitution at the 2- and 7-positions reverses the stability order, rendering the oxepine as the energetically favoured isomer due to the destabilizing eclipsing of the two methyl groups in benzene oxide (4) [38,40,51]. Thus, in contrast to the cycloheptatriene-norcaradiene (1-2) pair, the equilibrium constant for oxepine (3) and bicyclic benzene oxide (4) varies widely with solvent polarity and to some extent with temperature and substituents, making it possible to work with solutions highly enriched with either one or the other isomer [38,55]. The facile $\mathbf{3} \rightarrow \mathbf{4}$ valence isomerization [56-58], pioneered by the synthesis of 1,2-naphthalene oxide by Vogel and Klärner [1,59,60], is of considerable interest as arene oxides are intermediates in the oxidative metabolism of aromatic substrates [61-64]. In addition, also photo-oxidation of benzene creates this isomeric pair $[65,66]$.

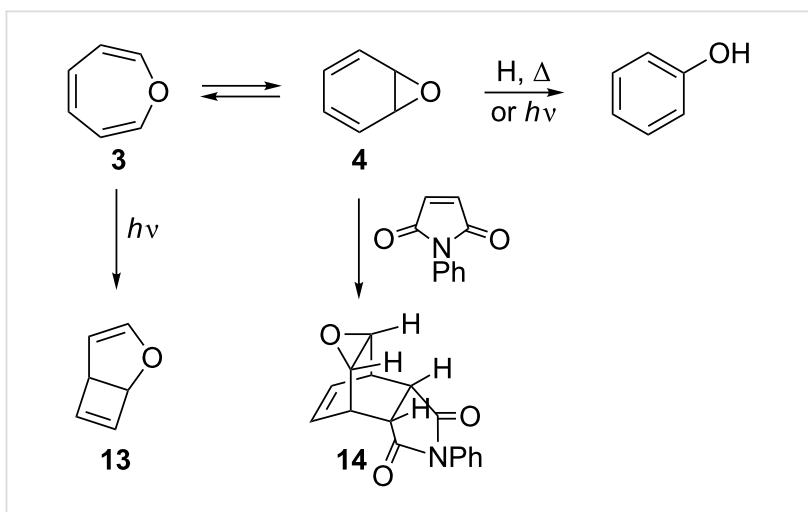

Scheme 4: Reactivity of oxepine (3) and benzene oxide (4).

Depicted in Scheme 4 are the most important reactions that the parent oxepine (3) and benzene oxide (4) can undergo. Irradiation of oxepine results in ring contraction yielding 2-oxabicyclo[2.3.0]hepta-3,6-diene (13) [38,51], while under thermal, photochemical or acidic conditions, the three-membered ring of bicyclic 4 opens, generating phenol $[67,68]$, in analogy to the all-carbon norcaradiene (2), which gives toluene. In addition, 4 undergoes highly selective Diels-Alder reactions, such as with
$N$-phenylmaleimide and dimethyl acetylenedicarboxylate, providing single anti-adducts (e.g., 14; Scheme 4) [61,69]. Theoretical calculations on model structures showed the anti cycloaddition to be the kinetically controlled path and the syn addition the thermodynamically favoured one [40].

\section{Thiepine - benzene sulfide}

The parent thiepine (5) is $7.0 \mathrm{kcal} \cdot \mathrm{mol}^{-1}$ less stable than benzene sulfide (6). This energy difference is much larger than for the oxygen homologues, because three-membered rings accommodate sulfur better than oxygen [40]. Nonetheless, bicyclic 6 has never been isolated, probably due to the low activation barrier for sulfur extrusion $[40,48,70]$, which occurs through a sequence of low-energy processes involving several sulfur-containing intermediates [71,72].

Thiepine (5) can be stabilized by $\mathrm{Fe}(\mathrm{CO})_{3}$ complexation (15; Figure 2) [73] or by decorating the seven-membered ring with substituents. The first isolated metal-free thiepine (16; Figure 2) was reported in 1974 by Reinhoudt and Kouwenhoven, who used electron-withdrawing groups to delocalize the $\pi$-electrons of the thiepine ring, but this species still eliminates sulfur at room temperature [74]. With the synthesis of the sterically shielded 2,7-di-tert-butylthiepine (17) (Figure 2), a relatively simple and thermally stable thiepine was obtained, allowing experimental studies of its chemical and physical properties [75]. A single-crystal X-ray analysis showed $\mathbf{1 7}$ to be less curved $\left(\alpha=49.6^{\circ}\right.$ and $\left.\beta=28.0^{\circ}\right)[70]$ than the computed structure of cyclohepta-1,3,5-triene $\left(1 ; \alpha=52.9^{\circ}, \beta=25.4^{\circ}\right)$ [14]; The MP2/6-31G(d) optimized geometry of the parent thiepine (5) $\left(\alpha=50.3^{\circ}\right.$ and $\left.\beta=30.8^{\circ}\right)[40]$ is similar to that of the molecular structure of 17 [76]. Benzannulation of the thiepine ring on both sides results in the thermally robust dibenzo $[b, f]$ thiepines, which are of interest for their potent biological activity, illustrated by the psychosedative and antipsychotic properties of zotepine (18; Figure 2) [76-80].

\section{$1 H$-Azepine - benzene imine}

The parent $1 H$-azepine (7) [81] was first generated in 1963 by Hafner, by the hydrolysis of ethyl- $1 H$-azepine- $N$-carboxylate<smiles>O=C(OC(F)(F)F)C1=CC=CSC=C1</smiles>

15<smiles>COC(=O)C1=CSC=C(C)C(C(=O)OC)=C1N1CCCC1</smiles>

16<smiles>CC(C)(C)C1=CC=CC=C(C(C)(C)C)S1</smiles>

17<smiles>CN(C)CCOC1=Cc2ccccc2Sc2ccc(Cl)cc21</smiles>

18

Figure 2: Stabilized thiepines 15-18 
with potassium hydroxide and subsequent protonation [82]. Because $1 H$-azepine is highly unstable and rapidly undergoes a $[1,3]$-H shift to $3 H$-azepine, only an X-ray structure determination at $-78{ }^{\circ} \mathrm{C}$ of an $\mathrm{N}$-substituted derivative was reported by Vogel et al. 17 years later [83-85]. The molecular structure of $N$-(phenoxycarbonyl)azepine displays a rather shallow boat structure $\left(\alpha=43.4^{\circ}\right.$ and $\left.\beta=21.6^{\circ}\right)$ [86], which is solely due to the N-substituent, as the CASSCF/3-21G optimized geometry showed a more curved $\beta$ angle of $36.4^{\circ}$ for the parent 7 [87].

Like the all-carbon analogues, the valence isomerization strongly favours the monocyclic form with an estimated preference of $7.9 \mathrm{kcal} \cdot \mathrm{mol}^{-1}$ at the B3LYP/6-31G(d) level for the parent system $(\mathbf{7} \rightarrow \mathbf{8})$ [42]. Also low temperature ${ }^{1} \mathrm{H}$ and ${ }^{13} \mathrm{C}$ NMR measurements on $\mathbf{1 9}$ display only small amounts of the bicyclic isomers 20 (Scheme 5) [79,88].

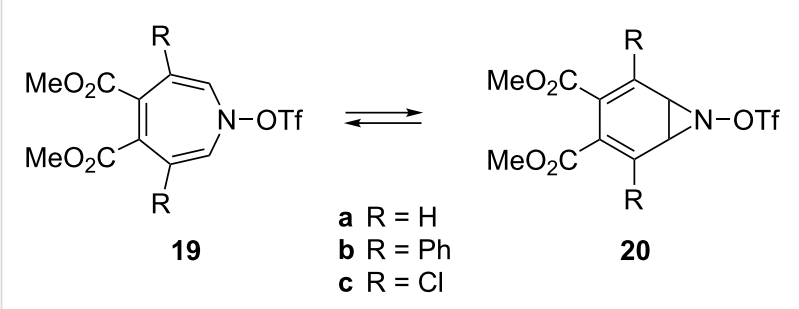

Scheme 5: Valence isomerization of $1 \mathrm{H}$-azepines.

The reluctance to form the bicyclic isomer dictates the reactivity of azepines, as they exhibit the characteristics of cyclic polyene chemistry, which is illustrated by the ability of the monocyclic isomer to undergo cycloadditions as a $2 \pi(\rightarrow \mathbf{2 1})$ [89], $4 \pi(\rightarrow \mathbf{2 2})$ [84,90], or $6 \pi(\rightarrow \mathbf{2 3}, \mathbf{2 4})$ [91,92] component (Scheme 6). In addition, azepine (7) rearranges photochemically to bicyclic 25 [93], and in the presence of an acid yields aniline derivatives 26 [94] in analogy to the cycloheptatriene and oxepine [95].

Like the thiepines, the benzannulated azepines have also received considerable attention due to their biological importance and pharmaceutical relevance [96]. For instance, 3H-3benzazepin-2-amines 27 possess antihypertensive activity [97], and all tricyclic dibenzo[ $b$,f]azepines (e.g., 28; Figure 3 ) bearing a basic side chain affect the central nervous system [98].

\section{H-Phosphepine - benzene phosphane}

Although the parent $1 H$-phosphepine (9) and its $2.5 \mathrm{kcal} \cdot \mathrm{mol}^{-1}$ more-stable valence isomer benzene phosphane (10) have never been isolated [45], there is evidence for the existence of the parent phosphatropylium ion (29; Figure 4), which was generated in the gas phase by collision activation between $\mathrm{PI}_{3}$ and benzene [99]. P-phenyl substitution stabilizes the phosphanor-

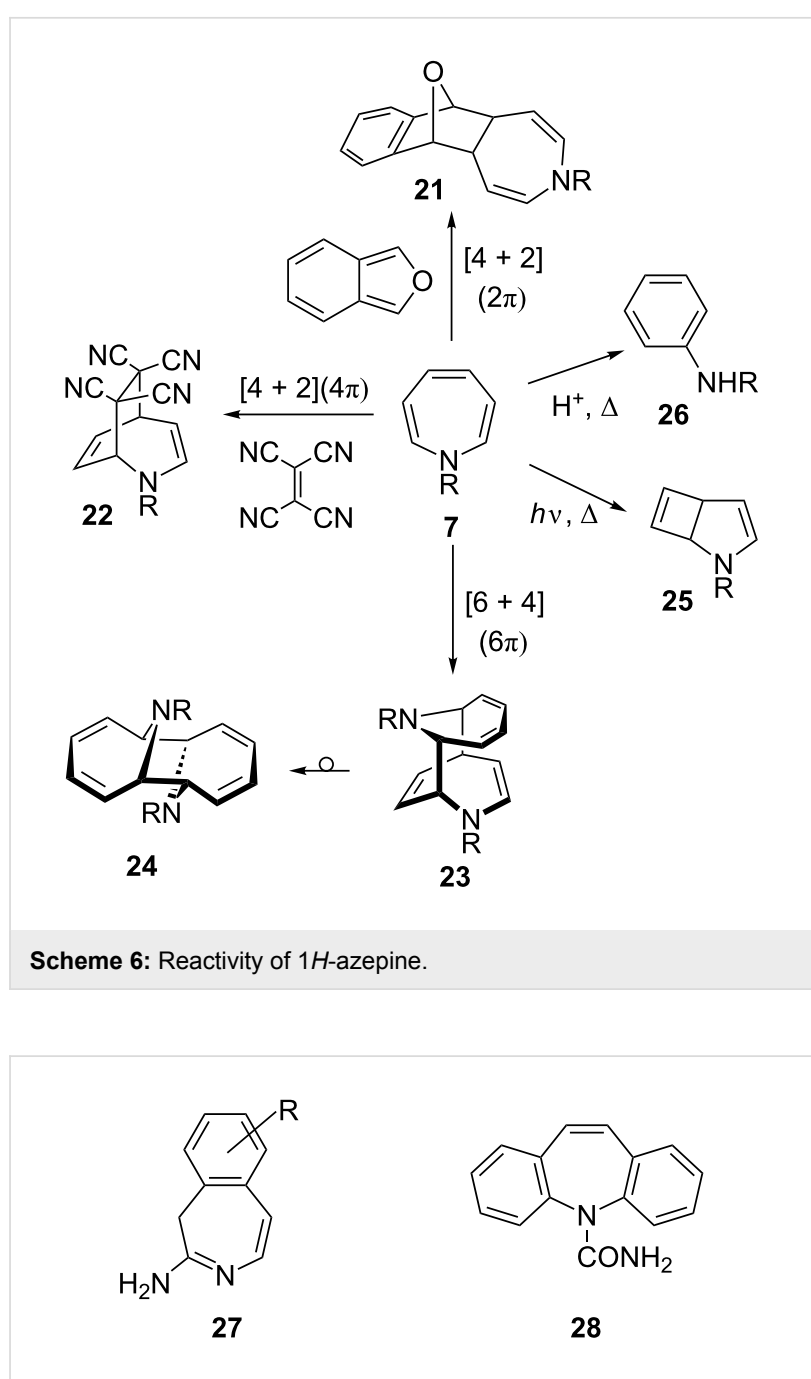

Figure 3: Benzannulated azepines 27 and 28.

caradiene $\left(\Delta E=4.8 \mathrm{kcal} \cdot \mathrm{mol}^{-1}\right)$, but this species has also never been observed experimentally [7]. The thermal instability of the phosphepines and their valence isomers is due to the facile decomposition of the bicyclic phosphanorcaradiene (10) into benzene and phosphinidene R-P [100]. However, the 7-membered ring can be stabilized by phosphorus oxidation (30; see Figure 4) [95], the introduction of bulky substituents at the 2 and 7 positions (31) [101], or benzannulation (e.g., $3 H$-benzophosphepine, 32) [7,102-107]. The single-crystal $\mathrm{X}$-ray structure analysis of phenyl-substituted phosphepine 33<smiles>CCC(C)C1=CC=CC=C([12CH2])P1P1c2ccccc2C=CP1P(=O)(CC(C)(C)C)c1ccccc1</smiles>

Figure 4: Reported phosphepines 29-32. 


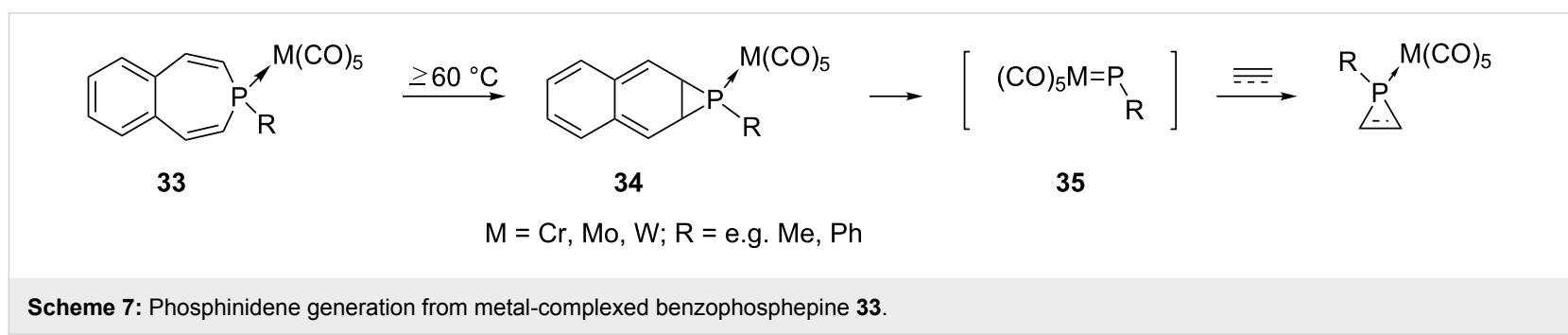

(Scheme 7) also showed a flattened-boat conformation $\left(\alpha=40.5^{\circ}, \beta=28.2^{\circ}\right)$ [5] compared to the metal-free parent structure $\left(\alpha=48.3^{\circ}, \beta=27.8^{\circ}\right)$, computed at the B3PW91/6$311+\mathrm{G}(\mathrm{d}, \mathrm{p})$ level [7].

Also for the phosphepine system [108], benzannulation leads to interesting targets. Namely, the thermal lability of the transition-metal-complexed $3 H$-benzophosphepine $\mathbf{3 3}$ was explored by Lammertsma et al. for the synthesis of a variety of organophosphorus compounds by means of $[1+2]$ cycloadditions of the in situ generated singlet phosphinidene 35 with olefins or acetylenes (Scheme 7) [5-9]. This approach has even lead to the detection of the transient phosphinidene species by employing electrospray ionization tandem mass spectrometry (ESIMS/MS); its gas-phase reactivity perfectly matches the well-established solution-phase chemistry [109]. Using these phosphinidenes $[110,111]$ led to the synthesis of unique P-ligands for catalysis [112,113] as well as to attractive building blocks for the creation of P-functionalized polymers [114,115].

\section{Conclusion}

The valence isomerization of cyclohepta-1,3,5-triene into the parent norcaradiene, and of their corresponding heteroelement analogues, has been reviewed with a focus on the chemical and physical properties of these fascinating species. The presence of a heteroatom has an impact on the stability of the heteropines, of which to date only the parent oxepine has been isolated. The generation of these (transient) heterocycles allowed the development of a rich chemistry, which has been extensively explored using the full toolbox of physical organic chemistry.

\section{Acknowledgements}

This work was supported by the Council for Chemical Sciences of the Netherlands Organization for Scientific Research (NWO/ $\mathrm{CW})$.

\section{References}

1. Vogel, E. Angew. Chem., Int. Ed. 2011, 50, 4278-4287. doi:10.1002/anie.201101347

2. Maier, G. Angew. Chem., Int. Ed. Engl. 1967, 6, 402-413. doi:10.1002/anie.196704021
3. Rodríguez-Hahn, L.; Esquivel, B.; Sánchez, A. A.; Cárdenas, J.; Tovar, O. G.; Soriano-García, M.; Toscano, A. J. Org. Chem. 1988, 53, 3933-3936. doi:10.1021/jo00252a010

4. Güney, M.; Daştan, A.; Balci, M. Helv. Chim. Acta 2005, 88, 830-838. doi:10.1002/hlca.200590061

5. Borst, M. L. G.; Bulo, R. E.; Winkel, C. W.; Gibney, D. J.; Ehlers, A. W.; Schakel, M.; Lutz, M.; Spek, A. L.; Lammertsma, K. J. Am. Chem. Soc. 2005, 127, 5800-5801. doi:10.1021/ja050817y

6. Borst, M. L. G.; Bulo, R. E.; Gibney, D. J.; Alem, Y.; de Kanter, F. J. J.; Ehlers, A. W.; Schakel, M.; Lutz, M.; Spek, A. L.; Lammertsma, K. J. Am. Chem. Soc. 2005, 127, 16985-16999. doi:10.1021/ja054885w

7. Jansen, H.; Slootweg, J. C.; Ehlers, A. W.; Lammertsma, K. Organometallics 2010, 29, 6653-6659. doi:10.1021/om1004379

8. Couzijn, E. P. A.; Ehlers, A. W.; Slootweg, J. C.; Schakel, M.; Krill, S.; Lutz, M.; Spek, A. L.; Lammertsma, K. Chem.-Eur. J. 2008, 14, 1499-1507. doi:10.1002/chem.200700958

9. Jansen, H.; Rosenthal, A. J.; Slootweg, J. C.; Ehlers, A. W.; Lutz, M.; Spek, A. L.; Lammertsma, K. Organometallics 2008, 27, 2868-2872. doi:10.1021/om800188h

10. Ladenburg, A. Liebigs Ann. Chem. 1883, 217, 74-149. doi:10.1002/jlac.18832170107

11. Traetteberg, M. J. Am. Chem. Soc. 1964, 86, 4265-4270. doi:10.1021/ja01074a008

12. Butcher, S. S. J. Chem. Phys. 1965, 42, 1833-1836.

13. Reed, T. B.; Libscomb, W. N. Acta Crystallogr. 1953, 6, 108. doi:10.1107/S0365110X53000399 Suitable crystals for an accurate X-ray determination could not be obtained for cyclohepta-1,3,5-triene.

14. Davis, R. E.; Tulinksy, A. Tetrahedron Lett. 1962, 3, 839-846. However the derivative 7,7-dimethylcycloheptatriene-3-carboxylic acid did result in suitable crystals.

15. Chen, Z.; Jiao, H.; Wu, J. I.; Herges, R.; Zhang, S. B.; von Ragué Schleyer, P. J. Phys. Chem. A 2008, 112, 10586-10594. doi:10.1021/jp802496m

16. Jarzeçki, A. A.; Gajewski, J.; Davidson, E. R. J. Am. Chem. Soc. 1999, 121, 6928-6935. doi:10.1021/ja984471। See for similar computational geometrical studies $\alpha=52.1^{\circ}, \beta=25.2^{\circ}$ determined at the $\operatorname{CASSCF}(6,6) / 6-31 \mathrm{G}(\mathrm{d})$ level.

17. Scott, A. P.; Agranat, I.; Biedermann, P. U.; Riggs, N. V.; Radom, L. J. Org. Chem. 1997, 62, 2026-2038. doi:10.1021/jo962407। $A=57.5^{\circ}, \beta=27.6^{\circ}$ determined at the B-LYP/6-31G(d) level.

18. Jensen, F. R.; Smith, L. A. J. Am. Chem. Soc. 1964, 86, 956-957. doi:10.1021/ja01059a065

19. Anet, F. A. L. J. Am. Chem. Soc. 1964, 86, 458-460. doi:10.1021/ja01057a034 
20. Nishinaga, T.; Izukawa, Y.; Komatsu, K. J. Phys. Org. Chem. 1998, 11, 475-477.

doi:10.1002/(SICl)1099-1395(199807)11:7<475::AID-POC991>3.0.C $0 ; 2-0$

See for determination of "Nuclear Independent Chemical Shift" (NICS(0), benzene-8.0 ppm) gives-4.2 ppm for 1 .

21. Herges, R.; Geuenich, D. J. Phys. Chem. A 2001, 105, 3214-3220. doi:10.1021/jp0034426

22. Maier, G. Angew. Chem., Int. Ed. Engl. 1967, 6, 812. doi:10.1002/anie.196708121

23. Lowry, T. H.; Richardson, K. S. Mechanism and Theory in Organic Chemistry, 4th ed.; Harper and Row: London, 1990.

24. Menzek, A.; Balci, M. Tetrahedron 1993, 49, 6071-6078. doi:10.1016/S0040-4020(01)87191-X And references therein.

25. Rubin, M. B. J. Am. Chem. Soc. 1981, 103, 7791-7792. doi:10.1021/ja00416a018

26. Hall, G. E.; Roberts, J. D. J. Am. Chem. Soc. 1971, 93, 2203-2207. doi:10.1021/ja00738a019

27. Tang, T.-H.; Lew, C. S. Q.; Cui, Y.-P.; Capon, B.; Csizmadia, I. G. J. Mol. Struct.: THEOCHEM 1994, 305, 149-164. doi:10.1016/0166-1280(94)80150-9

28. Woods, W. G. J. Org. Chem. 1958, 23, 110-112. doi:10.1021/jo01095a617

29. Klump, K. N.; Chesick, J. P. J. Am. Chem. Soc. 1963, 85, 130-132. doi:10.1021/ja00885a003

30. Berson, J. A.; Willcott, M. R., III. J. Am. Chem. Soc. 1965, 87, 2751-2752. doi:10.1021/ja01090a037

31. Berson, J. A.; Willcott, M. R., III. J. Am. Chem. Soc. 1965, 87 , 2752-2753. doi:10.1021/ja01090a038

32. Klärner, F.-G. Angew. Chem., Int. Ed. Engl. 1974, 13, 268-270. doi:10.1002/anie.197402681

33. Klärner, K.-G.; Yaşlak, S.; Wette, M. Chem. Ber. 1977, 110, 107-123. doi:10.1002/cber.19771100112

34. Klärner, K.-G.; Yaşlak, S.; Wette, M. Chem. Ber. 1979, 112, 1168-1188. doi:10.1002/cber.19791120412

35. Klärner, K.-G.; Brassel, B. J. Am. Chem. Soc. 1980, 102, 2469-2470. doi:10.1021/ja00527a062

36. Ter Borg, A. P.; Kloosterziel, H.; Van Meurs, N. Proc. Chem. Soc., London 1962, 359.

37. Weth, E.; Dreiding, A. S. Proc. Chem. Soc., London 1964, 59-60.

38. Berson, J. A.; Willcott, M. R., III. J. Am. Chem. Soc. 1966, 88, 2494-2502. doi:10.1021/ja00963a025 See for the methyl-substituted analogues.

39. Vogel, E.; Böll, W. A.; Günther, H. Tetrahedron Lett. 1965, 6, 609-615. doi:10.1016/S0040-4039(00)90005-4

40. Günther, H. Tetrahedron Lett. 1965, 6, 4085-4090. doi:10.1016/S0040-4039(01)99570-X

41. Pye, C. C.; Xidos, J. D.; Poirier, R. A.; Burnell, D. J. J. Phys. Chem. A 1997, 101, 3371-3376. doi:10.1021/jp9623498

42. Kassaee, M. Z.; Arshadi, S.; Haerizade, B. N.; Vessally, E. J. Mol. Struct.: THEOCHEM 2005, 731, 29-37. doi:10.1016/j.theochem.2005.02.087

43. Cremer, D.; Dick, B.; Christeu, D. J. Mol. Struct.: THEOCHEM 1984, 110, 277-291. doi:10.1016/0166-1280(84)80077-9

44. Kao, J. J. Comput. Chem. 1988, 9, 905-923. doi:10.1002/jcc.540090812

45. Jennings, W. B.; Rutherford, M.; Boyd, D. R.; Agarwal, S. K.; Sharma, N. D. Tetrahedron 1988, 44, 7551-7558. doi:10.1016/S0040-4020(01)86249-9
46. Jennings, W. B.; Rutherford, M.; Agarwal, S. K.; Boyd, D. R.; Malone, J. F.; Kennedy, D. A. J. Chem. Soc., Chem. Commun. 1986, 970-972. doi:10.1039/C39860000970

47. Kassaee, M. Z.; Cheshmehkani, A.; Musavi, S. M.; Majdi, M.; Motamedi, E. J. Mol. Struct.: THEOCHEM 2008, 865, 73-78. doi:10.1016/j.theochem.2008.06.025

48. Chen, Z.; Wannere, C. S.; Corminboeuf, C.; Puchta, R.; von Ragué Schleyer, P. Chem. Rev. 2005, 105, 3842-3888. doi:10.1021/cr030088+

The NICS value is obtained from NMR calculations of a ghost atom $(\mathrm{Bq})$ at the geometrical ring center $(\operatorname{NICS}(0))$, but the value $1 \AA$ above the ring (NICS(1)) is recommended, because a lack of $\sigma$ shielding makes it a better measure of $\pi$-electron delocalization.

49. Kassaee, M. Z.; Musavi, S. M.; Momeni, M. R.; Shakib, F. A.; Ghambarian, M. J. Mol. Struct.: THEOCHEM 2008, 861, 117-121. doi:10.1016/j.theochem.2008.04.031 See for IAO-B3LYP/6-311G(d)//B3LYP/6-311G(d) level of theory.

50. Karney, W. L.; Kastrup, C. J.; Oldfield, S. P.; Rzepa, H. S. J. Chem. Soc., Perkin Trans. 2 2002, 388-392. doi:10.1039/b111369k

51. Dewar, M. J. S.; Trinajstić, N. J. Am. Chem. Soc. 1970, 92, 1453-1459. doi:10.1021/ja00709a001

52. Hess, B. A., Jr.; Schaad, L. J. J. Am. Chem. Soc. 1973, 95, 3907-3912. doi:10.1021/ja00793a013

53. Vogel, E.; Schubart, R.; Böll, W. A. Angew. Chem., Int. Ed. Engl. 1964, 3, 510. doi:10.1002/anie.196405101

54. van Tamelen, E. E.; Carty, D. T. J. Am. Chem. Soc. 1967, 89, 3922-3923. doi:10.1021/ja00991a056

55. Vogel, E.; Günther, H. Angew. Chem., Int. Ed. Engl. 1967, 6, 385-401. doi:10.1002/anie.196703851

56. Belen'kll, L. I. Oxepanes and Oxepines. In Seven-membered and Larger Rings and Fused Derivatives; Newkome, G. R., Ed.; Comprehensive Heterocyclic Chemistry II, Vol. 9; Elsevier Science Ltd.: Oxford, 1996; pp 45-66. doi:10.1016/B978-008096518-5.00210-0

57. Bock, C. W.; George, P.; Stezowski, J. J.; Glusker, J. P. Struct. Chem. 1989, 1, 33-39. doi:10.1007/BF00675782

58. Hayes, D. M.; Nelson, S. D.; Garland, W. A.; Kollman, P. A. J. Am. Chem. Soc. 1980, 102, 1255-1262. doi:10.1021/ja00524a007

59. Vogel, E.; Klärner, F.-G. Angew. Chem., Int. Ed. Engl. 1968, 7, 374-375. doi:10.1002/anie.196803742

60. Klärner, F.-G.; Vogel, E. Angew. Chem., Int. Ed. Engl. 1973, 12, 840-841. doi:10.1002/anie.197308401

61. Jerina, D. M.; Daly, J. W.; Witkop, B. In Biogenic Amines and Physiological Membranes in Drug Therapy, Part B; Biel, J. H.; Abood, L. G., Eds.; Marcel Dekker: New York, 1971; pp 413-476.

62. Daly, J. W.; Jerina, D. M.; Witkop, B. Experientia 1972, 28, 1129-1149. doi:10.1007/BF01946135

63. Jerina, D. M.; Daly, J. W. Science 1974, 185, 573-582. doi:10.1126/science.185.4151.573

64. Boyd, D. R.; Sharma, N. D. Chem. Soc. Rev. 1996, 25, 289-296. doi:10.1039/cs9962500289

65. Klotz, B.; Barnes, I.; Becker, K. H.; Golding, B. T. J. Chem. Soc., Faraday Trans. 1997, 93, 1507-1516. doi:10.1039/a606152d

66. Henderson, A. P.; Mutlu, E.; Leclercq, A.; Bleasdale, C.; Clegg, W.; Henderson, R. A.; Golding, B. T. Chem. Commun. 2002, 1956-1957. doi:10.1039/b205079j 
67. George, P.; Bock, C. W.; Glusker, J. P. J. Phys. Chem. 1990, 94, 8161-8168. doi:10.1021/j100384a034 In the presence of acid, protonation results in a carbocation intermediate and does not generate a radical species.

68. Holovka, J. M.; Gardner, P. D. J. Am. Chem. Soc. 1967, 89, 6390-9391. doi:10.1021/ja01000a092

69. Gillard, J. R.; Newlands, M. J.; Bridson, J. N.; Burnell, D. J. Can. J. Chem. 1991, 69, 1337-1343. doi:10.1139/v91-199

70. Field, L.; Tuleen, D. L. Monocyclic Seven-Membered Rings Containing Sulfur. In Seven-Membered Heterocyclic Compounds Containing Oxygen and Sulfur; Rosowsky, A., Ed.; Wiley Interscience: New York, 1972; Chapter 10.

71. Miller, K. J.; Moschner, K. F.; Potts, K. T. J. Am. Chem. Soc. 1983, 105, 1705-1712. doi:10.1021/ja00345a001

72. Gleiter, R.; Krennrich, G.; Cremer, D.; Yamamoto, K.; Murata, I. J. Am. Chem. Soc. 1985, 107, 6874-6879. doi:10.1021/ja00310a022

73. Nishino, K.; Takagi, M.; Kawata, T.; Murata, I.; Inanaga, J.; Nakasuji, K. J. Am. Chem. Soc. 1991, 113, 5059-5060. doi:10.1021/ja00013a051

74. Reinhoudt, D. N.; Kouwenhoven, C. G. Tetrahedron 1974, 30 , 2093-2098. doi:10.1016/S0040-4020(01)97344-2

75. Yamamoto, K.; Yamazaki, S.; Kohashi, Y.; Murata, I.; Kai, Y.; Kanehisa, N.; Miki, K.; Kasai, N. Tetrahedron Lett. 1982, 23, 3195-3198. doi:10.1016/S0040-4039(00)88594-9

76. Yamamoto, K.; Yamazaki, S. Thiepanes and Thiepines. In Seven-membered and Larger Rings and Fused Derivatives; Newkome, G. R., Ed.; Comprehensive Heterocyclic Chemistry II, Vol. 9; Elsevier Science Ltd.: Oxford, 1996; pp 67-111. doi:10.1016/B978-008096518-5.00211-2

77. Ueda, I.; Sato, Y.; Maeno, S.; Umio, S. Chem. Pharm. Bull. 1978, 26, 3058-3070.

78. Higashi, Y.; Momotani, Y.; Suzuki, E.; Kaku, T. Pharmacopsychiatry 1987, 20, 8-11. doi:10.1055/s-2007-1017124

79. Schwan, A. L. Product Subclass 4: Benzothiepins and Selenium/Tellurium Analogues. In Science of Synthesis; Weinreb, S. M., Ed.; Thieme: Stuttgart, Germany, 2004; Vol. 17, pp 717-748.

80. Protiva, M. J. Heterocycl. Chem. 1996, 33, 497-521. doi:10.1002/jhet.5570330301

81. Paquette, L. A. Angew. Chem., Int. Ed. Engl. 1971, 10, 11-20. doi:10.1002/anie.197100111

82. Hafner, K. Angew. Chem., Int. Ed. Engl. 1964, 3, 165-173. doi:10.1002/anie.196401651

83. Vogel, E.; Altenbach, H.-J.; Drossard, J.-M.; Schmickler, H.; Stegelmeier, H. Angew. Chem., Int. Ed. Engl. 1980, 19, 1016-1018. doi:10.1002/anie.198010161

84. Smalley, R. K. Azepines. In Part 5: Small and Large Rings; Lwowski, W., Ed.; Comprehensive Heterocyclic Chemistry, Vol. 7; Elsevier Science Ltd.: Oxford, 1984; p 491.

85. Smalley, R. K. Azepines. In Part 5: Small and Large Rings; Lwowski, W., Ed.; Comprehensive Heterocyclic Chemistry, Vol. 7; Elsevier Science Ltd.: Oxford, 1984; p 543.

86. Lindner, H. J.; von Gross, B. Chem. Ber. 1972, 105, 434-440. doi:10.1002/cber.19721050208

87. Smith, D. A.; Bitar, J. J. Org. Chem. 1993, 58, 6-8. doi:10.1021/jo00053a003

88. Prinzbach, H.; Babsch, H.; Fritz, H.; Hug, P. Tetrahedron Lett. 1977, 18, 1355-1358. doi:10.1016/S0040-4039(01)93042-4

89. Paquette, L. A.; Kuhla, D. E.; Barrett, J. H.; Leichter, L. M. J. Org. Chem. 1969, 34, 2888-2896. doi:10.1021/jo01262a018
90. van den Hende, J. H.; Kende, A. S. Chem. Commun. 1965, 384-385. doi:10.1039/c19650000384

91. Paquette, L. A.; Barrett, J. H. J. Am. Chem. Soc. 1966, 88, 2590-2591. doi:10.1021/ja00963a041

92. Paquette, L. A.; Barrett, J. H.; Kuhla, D. E. J. Am. Chem. Soc. 1969, 91, 3616-3624. doi:10.1021/ja01041a032

93. Paquette, L. A.; Barrett, J. H. J. Am. Chem. Soc. 1966, 88, 1718-1722. doi:10.1021/ja00960a028

94. Paquette, L. A.; Kuhla, D. E.; Barrett, J. H. J. Org. Chem. 1969, 34, 2879-2884. doi:10.1021/jo01262a016

95. Le Count, D. J. Azepines and their Fused-ring Derivatives. In Seven-membered and Larger Rings and Fused Derivatives; Newkome, G. R., Ed.; Comprehensive Heterocyclic Chemistry II, Vol. 9; Elsevier Science Ltd.: Oxford, 1996; pp 45-66. doi:10.1016/B978-008096518-5.00209-4 See for more details on azepines.

96. Meigh, J.-P. K. Product Subclass 6: Benzazepines and Their Group 15 Analogues. In Science of Synthesis; Weinreb, S. M., Ed.; Thieme: Stuttgart, Germany, 2004; Vol. 17, pp 717-748. See for more synthetic routes.

97. Robey, R. L.; Copley-Merriman, C. R.; Phelps, M. A. J. Heterocycl. Chem. 1989, 26, 779-783. doi:10.1002/jhet.5570260350

98. Steiner, G.; Franke, A.; Hädicke, E.; Lenke, D.; Teschendorf, H.-J.; Hofmann, H.-P.; Kreiskott, H.; Worstmann, W. J. Med. Chem. 1986, 29, 1877-1888. doi:10.1021/jm00160a015

99. Muedas, C. A.; Schröder, D.; Sülzle, D.; Schwarz, H. J. Am. Chem. Soc. 1992, 114, 7582-7584. doi:10.1021/ja00045a052

100.Märkl, G.; Schubert, H. Tetrahedron Lett. 1970, 11, 1273-1276. doi:10.1016/S0040-4039(01)91607-7

101. Märkl, G.; Burger, W. Angew. Chem., Int. Ed. Engl. 1984, 23 , 894-895. doi:10.1002/anie.198408941

102. Märkl, G.; Burger, W. Tetrahedron Lett. 1983, 24, 2545-2548. doi:10.1016/S0040-4039(00)81977-2

103. Kurita, J.; Shiratori, S.; Yasuike, S.; Tsuchiya, T. J. Chem. Soc., Chem. Commun. 1991, 1227-1228. doi:10.1039/C39910001227

104. Yasuike, S.; Ohta, H.; Shiratori, S.; Kurita, J.; Tsuchiya, T. J. Chem. Soc., Chem. Commun. 1993, 1817-1819. doi:10.1039/C39930001817

105. Segall, Y.; Shirin, E.; Granoth, I. Phosphorus Sulfur Relat. Elem. 1980, 8, 243-254. doi:10.1080/03086648008078196

106. Yasuike, S.; Kiharada, T.; Kurita, J.; Tsuchiya, T. Chem. Commun. 1996, 2183-2184. doi:10.1039/cc9960002183

107. Yasuike, S.; Kiharada, T.; Tsuchiya, T.; Kurita, J. Chem. Pharm. Bull. 2003, 51, 1283-1288. doi:10.1248/cpb.51.1283

108.Pabel, M.; Wild, S. B. Rings containing Phosphorus. In Seven-membered and Larger Rings and Fused Derivatives; Newkome, G. R., Ed.; Comprehensive Heterocyclic Chemistry II, Vol. 9; Elsevier Science Ltd.: Oxford, 1996; pp 947-950. doi:10.1016/B978-008096518-5.00242-2 See for more details on phosphepines.

109. Jansen, H.; Samuels, M. C.; Couzijn, E. P. A.; Slootweg, J. C.; Ehlers, A. W.; Chen, P.; Lammertsma, K. Chem.-Eur. J. 2010, 16, 1454-1458. doi:10.1002/chem.200902715

110.Slootweg, J. C.; Lammertsma, K. Product Class 2: Phosphinidenes and termian Phosphinidene Complexes. In Science of Synthesis; Mathey, F., Ed.; Thieme: Stuttgart, Germany, 2009; Vol. 42, pp 15-36.

111.Lammertsma, K. Top. Curr. Chem. 2003, 229, 95-119. doi:10.1007/b11152 
112. Mathey, F. Angew. Chem., Int. Ed. 2003, 42, 1578-1604. doi:10.1002/anie.200200557

113. Le Floch, P. Coord. Chem. Rev. 2006, 250, 627-681.

doi:10.1016/j.ccr.2005.04.032

114.Noonan, K. J. T.; Gates, D. P. Angew. Chem., Int. Ed. 2006, 45,

7271-7274. doi:10.1002/anie.200602955

115. Gates, D. P. Top. Curr. Chem. 2005, 250, 107-126.

doi:10.1007/b100983

\section{License and Terms}

This is an Open Access article under the terms of the Creative Commons Attribution License

(http://creativecommons.org/licenses/by/2.0), which permits unrestricted use, distribution, and reproduction in any medium, provided the original work is properly cited.

The license is subject to the Beilstein Journal of Organic Chemistry terms and conditions:

(http://www.beilstein-journals.org/bjoc)

The definitive version of this article is the electronic one which can be found at: doi:10.3762/bjoc.7.201 